\title{
Expression of Caveolin-1, Caveolin-2 and Caveolin-3 in Thyroid Cancer and Stroma
}

\author{
Dokyung Kim ${ }^{\mathrm{a}}$ Haeryoung Kim ${ }^{\mathrm{b}}$ Ja Seung Koo ${ }^{\mathrm{a}}$

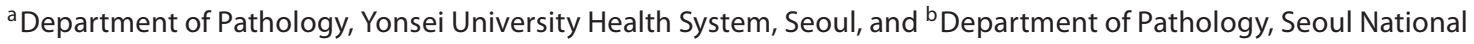 \\ University Bundang Hospital, Seongnam, South Korea
}

\section{Key Words}

Anaplastic carcinoma $\cdot$ Caveolin $\cdot$ Epithelial-mesenchymal transition $\cdot$ Myofibroblast $\cdot$ Thyroid cancer

\begin{abstract}
Objective: To study the expression status of caveolin-1, caveolin-2 and caveolin-3 in the epithelial and stromal compartments of conventional papillary thyroid carcinoma (PTC), diffuse sclerosing variant of papillary carcinoma (DSVPC) and anaplastic carcinoma (AC). Methods: Tissue microarrays were constructed from 70 PTC, 41 DSVPC and 12 $A C$, and immunohistochemical stains were performed with caveolin-1, caveolin-2, caveolin-3, cytokeratin, vimentin and $\mathrm{E}$-cadherin. The expression status of these markers in the epithelial and stromal cells was evaluated, and the results were correlated with the clinicopathologic variables. Results: Epithelial caveolin-3 expression was absent in the majority of PTC and DSPVC, and was significantly increased in AC ( $p<$ 0.001). The stromal expression of caveolin-1, caveolin-2 and caveolin-3 increased in frequency from PTC to DSVPC to AC, and was significantly increased in the stroma of $A C$ ( $p<$ 0.001). Cytokeratin and E-cadherin were more frequently negative in AC compared to PTC $(p=0.003)$ and DSVPC $(p<$ 0.001), while vimentin was more frequently expressed in $A C$ compared to PTC and DSVPC (both $\mathrm{p}<0.001$ ). Conclusion:
\end{abstract}

Epithelial caveolin-3 expression is increased in AC compared to PTC and DSVPC, and this may be linked to the epithelialmesenchymal transition process of AC. In addition, stromal caveolin-1, caveolin-2 and caveolin-3 expression was more frequent in AC compared to PTC and DSVPC, and the specific expression of caveolin-3 in the stroma of AC could suggest a possible role of myofibroblasts.

Copyright $\odot 2012$ S. Karger AG, Basel

\section{Introduction}

Caveolin is an integral membrane protein which is necessary for the invagination of the plasma membrane forming caveolae, and has been identified in a wide variety of tissues, including adipocytes, smooth muscle cells, endothelial cells and fibroblasts [1]. Three types of caveolins exist, namely caveolin-1, caveolin-2 and caveolin-3, and these proteins have been recognized to play central roles in the intracellular trafficking of cellular components and signal transduction. There is increasing evidence for the association of caveolins with carcinogenesis, especially in breast cancer: loss of caveolin-1 in the

D.K. and H.K. have contributed equally to this work.

\section{KARGER}

Fax +4161306 1234 E-Mail karger@karger.ch www.karger.com
(ㄷ) 2012 S. Karger AG, Basel $1015-2008 / 12 / 0791-0001 \$ 38.00 / 0$

Accessible online at:

www.karger.com/pat
Ja Seung Koo, MD

Yonsei University College of Medicine, Severance Hospital

250 Seongsanno, Seodaemun-gu

Seoul 120-752 (South Korea)

Tel. +82 22228 1772, E-Mail kjs1976@yuhs.ac 
Table 1. Clone, dilution and source of antibodies used

\begin{tabular}{|c|c|c|c|}
\hline Antibody & Clone & Dilution & Source \\
\hline \multicolumn{4}{|c|}{ Caveolin proteins } \\
\hline Caveolin-1 & No. 2,297 & $1: 50$ & $\begin{array}{l}\text { BD Biosciences, San } \\
\text { Jose, Calif., USA }\end{array}$ \\
\hline Caveolin-2 & No. 2,220 & $1: 200$ & $\begin{array}{l}\text { Abcam, Cambridge } \\
\text { UK }\end{array}$ \\
\hline Caveolin-3 & polyclonal & $1: 100$ & Abcam \\
\hline \multicolumn{4}{|c|}{ Epithelial-mesenchymal transition-related } \\
\hline Cytokeratin & AE1/AE3 & $1: 300$ & $\begin{array}{l}\text { Dako, Glostrup, } \\
\text { Denmark }\end{array}$ \\
\hline Vimentin & V9 & $1: 1,200$ & Dako \\
\hline E-cadherin & SPM471 & $1: 150$ & $\begin{array}{l}\text { Thermo Scientific, } \\
\text { Rockford, Ill., USA }\end{array}$ \\
\hline SMA & M0851 & $1: 1,000$ & Dako \\
\hline
\end{tabular}

stroma of breast cancer has been associated with early tumor recurrence, metastasis, resistance to treatment and a poor clinical outcome [2], thereby suggesting that caveolin-1 expression in breast cancer stroma may have tumor-suppressing properties.

Thyroid cancer is a common malignancy occurring in approximately $1 \%$ of the general population. The most common cell of origin is the thyroid follicular cell (95\%), and the most common type of thyroid cancer is papillary thyroid carcinoma (PTC). Prominent tumor stroma formation is a characteristic of PTC, especially in the diffuse sclerosing variant of papillary carcinoma (DSVPC) where prominent sclerosis is included in the diagnostic criteria [3]. In thyroid cancers, caveolin-1 expression was demonstrated in PTC, while follicular carcinomas did not express the protein $[4,5]$. However, the expression status of caveolin in tumor stroma of thyroid cancers has not yet been reported. The stroma which constitutes the tumor microenvironment is composed of cellular components, including fibroblasts, myofibroblasts, leukocytes, endothelial cells and bone marrow-derived cells, and extracellular matrix $[6,7]$. The stroma closely interacts with the cellular component of the tumor, and plays important roles in tumorigenesis and tumor progression [8-11].

In this study, we studied the expression status of caveolin-1, caveolin-2 and caveolin-3 in epithelial and stromal cells of conventional PTC, DSVPC and anaplastic carcinoma (AC) and correlated the results with the clinicopathological variables.

\section{Subjects and Methods}

\section{Patient Selection}

123 surgically excised thyroid cancer cases obtained from January 1995 to December 2009 were selected from the pathology files of Severance Hospital. The cases comprised 70 PTC, 41 DSVPC and 12 AC. PTC and DSVPC specimens were obtained by total thyroidectomy with lymph node dissection. Total thyroidectomy was performed for 6 cases of AC and the remaining 6 cases were obtained by excisional biopsy. Lymph node dissection was performed for 3 AC patients. Clinicopathologic data were obtained from the patients' medical records and included age at diagnosis, disease recurrence, metastasis, current status and length of follow-up. The tumor size, location (right or left lobe), extent (confined to the thyroid parenchyme or with extrathyroidal spread) and number of metastatic lymph nodes were also noted from review of the slides as well as the surgical pathology reports. The imaging and intraoperative records were reviewed in order to evaluate tumor size, location and extent of AC cases for which only excisional biopsies were performed. The size of DSVPC was measured from the largest predominant nodule and intrathyroidal metastases were not measured. ACs were classified according to the cell type as follows: spindle cell type, undifferentiated type, squamoid type and small cell type. This study was approved by the Institutional Review Board of Severance Hospital.

\section{Tissue Microarray}

Representative areas were selected on hematoxylin-eosinstained slides and a corresponding spot was marked on the surface of the matching paraffin block. Five-millimeter core biopsies were taken from selected areas and placed into a $5 \times 4$ recipient block. More than 2 tissue cores were extracted from each case to minimize extraction bias. Each tissue core was assigned a unique tissue microarray location number that was linked to a database containing other clinicopathologic data.

\section{Immunohistochemistry}

All immunohistochemical stains were performed using formalin-fixed, paraffin-embedded tissue sections. The antibodies used for immunohistochemistry are shown in table 1. Five-micrometer-thick sections were obtained with a microtome, transferred to adhesive slides and dried at $62^{\circ} \mathrm{C}$ for $30 \mathrm{~min}$. After incubation with primary antibodies, immunodetection was performed with biotinylated anti-mouse immunoglobulin, followed by peroxidase-labeled streptavidin using a labeled streptavidin biotin kit with 3,3'-diaminobenzidine chromogen as substrate. Optimal primary antibody incubation time and concentration were determined via serial dilution for each immunohistochemical assay with an identically fixed and embedded tissue block. Slides were counterstained with Harris hematoxylin. The staining was interpreted by 2 pathologists (J.S.K. and D.K.) under a multiview microscope. All immunohistochemical stains were assessed by light microscopy, and the stain results for caveolin-1, caveolin-2, caveolin-3, cytokeratin, vimentin, E-cadherin and smooth muscle actin (SMA) were scored semi-quantitatively as negative ( 0 , no staining), weak ( 1 , staining of less than $30 \%$ of epithelial or stromal cells), moderate (2, staining of $30-60 \%$ of epithelial or stromal cells) and strong (3, staining of more than $60 \%$ of epithelial or stromal cells). The expression of caveolin-1, caveolin-2 and caveolin-3 as well as SMA were considered as positive when more 
Table 2. Patient characteristics

\begin{tabular}{|c|c|c|c|c|c|}
\hline Parameters & $\begin{array}{l}\text { Total } \\
(\mathrm{n}=123)\end{array}$ & $\begin{array}{l}\text { PTC } \\
(\mathrm{n}=70)\end{array}$ & $\begin{array}{l}\text { DSVPC } \\
(\mathrm{n}=41)\end{array}$ & $\begin{array}{l}\mathrm{AC} \\
(\mathrm{n}=12)\end{array}$ & $\mathrm{p}$ value \\
\hline Age $\geq 45$ years & $51(41.5 \%)$ & $36(51.4 \%)$ & $3(7.3 \%)$ & $12(100.0 \%)$ & $<0.001$ \\
\hline Sex & & & & & 0.945 \\
\hline Female & $101(82.1 \%)$ & $58(82.9 \%)$ & $33(80.5 \%)$ & $10(83.3 \%)$ & \\
\hline Male & $22(17.9 \%)$ & $12(17.1 \%)$ & $8(19.5 \%)$ & $2(16.7 \%)$ & \\
\hline Mean tumor size, $\mathrm{cm}$ & $2.6(1-8.0)$ & $2.3(1.2-6.5)$ & $2.1(1.0-4.5)$ & $5.9(4.0-8.0)$ & $<0.001$ \\
\hline Tumor laterality & & & & & 0.010 \\
\hline Right & $48(39.0 \%)$ & $23(32.9 \%)$ & $25(61.0 \%)$ & $8(66.7 \%)$ & \\
\hline Left & $19(15.4 \%)$ & $12(17.1 \%)$ & $7(17.0 \%)$ & 0 & \\
\hline Bilateral & $56(45.5 \%)$ & $35(50.0 \%)$ & $9(22.0 \%)$ & $4(33.3 \%)$ & \\
\hline Mean metastatic lymph nodes & $7.9(0-39)$ & $5.0(0-29)$ & $14.2(0-39)$ & $2.7(0-9)$ & $<0.001^{*}$ \\
\hline Extrathyroidal spread & $105(85.4 \%)$ & $59(84.3 \%)$ & $34(82.9 \%)$ & $12(100.0 \%)$ & 0.314 \\
\hline Mean follow-up duration, months & $28.8(1-130)$ & $29.5(8-64)$ & $34.3(3-130)$ & $6.3(1-24)$ & 0.001 \\
\hline Tumor recurrence & $8(6.5 \%)$ & $1(1.4 \%)$ & $7(17.1 \%)$ & 0 & $0.003^{*}$ \\
\hline Tumor metastasis & $4(3.3 \%)$ & 0 & $4(9.8 \%)$ & 0 & $0.016^{*}$ \\
\hline Tumor-related deaths & $11(8.9 \%)$ & 0 & 0 & $11(91.7 \%)$ & $<0.001$ \\
\hline
\end{tabular}

Figures in parentheses are ranges, unless indicated otherwise. ${ }^{*}$ Fisher's exact test between PTC and DSVPC.

than weak staining was identified. Stromal cell staining was assessed only in spindle-shaped mesenchymal cells and other components of the peritumoral stroma such as endothelial cells were excluded from evaluation.

\section{Statistical Analysis}

Data were analyzed using SPSS for Windows, version 18.0 (SPSS Inc., Chicago, Ill., USA). For determination of statistical significance among thyroid carcinoma subtypes regarding various parameters, Student's t test, Fisher's exact test and $\chi^{2}$ test were used for continuous and categorical variables. A p value of less than 0.05 was considered statistically significant.

\section{Results}

\section{DSVPC and AC Are Associated with Aggressive}

Clinicopathologic Characteristics

The clinicopathologic characteristics of the patients are summarized in table 2. Seventy cases of PTC, 41 DSVPC and $12 \mathrm{AC}$ were included in the study. Of the $12 \mathrm{AC}, 7$ (58.3\%) cases were of the undifferentiated type, 3 (25.0\%) were of the squamoid types, $1(8.3 \%)$ was of the spindle cell type and $1(8.3 \%)$ case was of the small cell type. All AC patients were older than 45 years of age, and DSVPC patients were mostly younger than 45 years $(92.7 \%$; $p<$ $0.001)$. The AC were significantly larger than PTC and DSVPC $(\mathrm{p}<0.001)$ and all AC were associated with extrathyroidal spread. DSVPC were associated with more ex-
Table 3. Expression of caveolin-1, caveolin-2 and caveolin-3 in PTC, DSVPC and AC

\begin{tabular}{|c|c|c|c|c|c|}
\hline & $\begin{array}{l}\text { Total } \\
(\mathrm{n}=123)\end{array}$ & $\begin{array}{l}\text { PTC } \\
(n=70)\end{array}$ & $\begin{array}{l}\text { DSVPC } \\
(\mathrm{n}=41)\end{array}$ & $\begin{array}{l}\mathrm{AC} \\
(\mathrm{n}=12)\end{array}$ & $\begin{array}{l}\mathrm{p} \\
\text { value }\end{array}$ \\
\hline \multicolumn{6}{|c|}{ Epithelial compartment } \\
\hline \multicolumn{5}{|c|}{ Caveolin-1 } & \multirow[t]{3}{*}{0.533} \\
\hline Positive & $53(43.1)$ & $29(41.4)$ & $17(41.5)$ & $7(58.3)$ & \\
\hline Negative & $70(56.9)$ & $41(58.6)$ & $24(58.5)$ & $5(41.7)$ & \\
\hline \multicolumn{5}{|l|}{ Caveolin-2 } & \multirow[t]{3}{*}{0.022} \\
\hline Positive & $93(75.6)$ & $59(84.3)$ & $25(61.0)$ & $9(75.0)$ & \\
\hline Negative & $30(24.4)$ & $11(15.7)$ & $16(39.0)$ & $3(25.0)$ & \\
\hline \multicolumn{5}{|l|}{ Caveolin-3 } & \multirow[t]{3}{*}{$<0.001$} \\
\hline Positive & $9(7.3)$ & $1(1.4)$ & $2(4.9)$ & $6(50.0)$ & \\
\hline Negative & $114(92.7)$ & $69(98.6)$ & $39(95.1)$ & $6(50.0)$ & \\
\hline \multicolumn{6}{|c|}{ Stromal compartment } \\
\hline \multicolumn{5}{|c|}{ Caveolin-1 } & \multirow[t]{3}{*}{$<0.001$} \\
\hline Positive & $26(21.1)$ & $6(8.6)$ & $15(36.6)$ & $5(41.7)$ & \\
\hline Negative & $97(78.9)$ & $64(91.4)$ & $26(63.4)$ & $7(58.3)$ & \\
\hline \multicolumn{5}{|l|}{ Caveolin-2 } & \multirow[t]{3}{*}{$<0.001$} \\
\hline Positive & $22(17.9)$ & 0 & $15(36.6)$ & $7(58.3)$ & \\
\hline Negative & $101(82.1)$ & $70(100.0)$ & $26(63.4)$ & $5(41.7)$ & \\
\hline \multicolumn{5}{|c|}{ Caveolin-3 } & \multirow[t]{3}{*}{$<0.001$} \\
\hline Positive & $3(2.4)$ & 0 & 0 & $3(25.0)$ & \\
\hline Negative & $120(97.6)$ & $70(100.0)$ & $41(100.0)$ & $9(75.0)$ & \\
\hline
\end{tabular}

Figures in parentheses are percentages. 


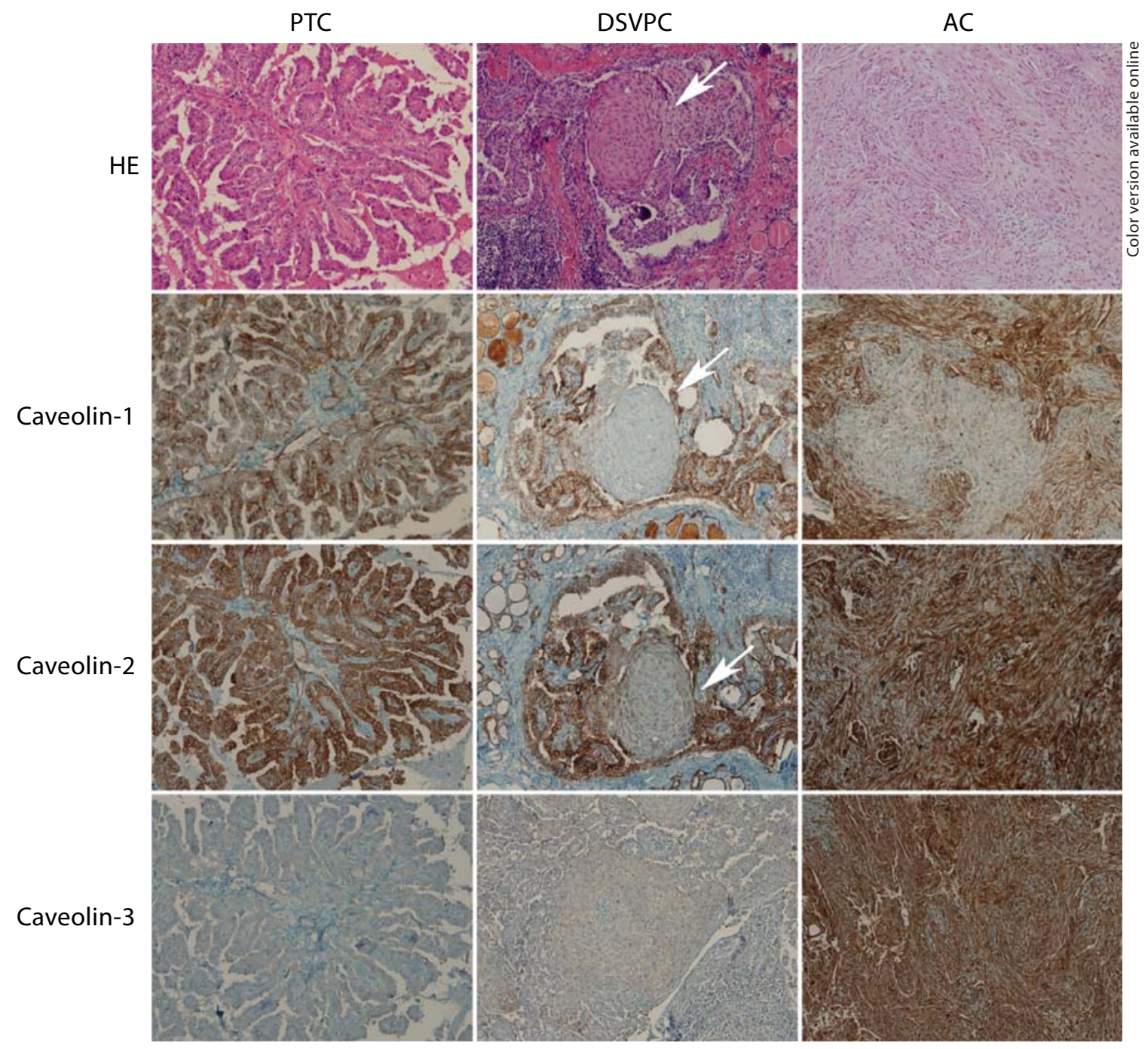

Fig. 1. Expression patterns of caveolin-1, caveolin-2, and caveolin-3 in epithelial and stromal components of thyroid cancer $(\times 100)$. PTC and DSVPC demonstrate epithelial caveolin-1 and caveolin-2 expression, and the squamous cell nests in DSVPC are negative for caveolin-1 and caveolin-2 expression (white arrows).
Caveolin-3 is not expressed in PTC and DSVPC. AC shows desmoplastic stroma and strong expression of caveolin-2 and caveolin-3 in both epithelial and stromal compartments, while caveolin-1 is more strongly expressed in the stroma compared to the epithelial component. tensive lymph node metastasis $(\mathrm{p}<0.001)$, more frequent postoperative tumor recurrence $(\mathrm{p}=0.002)$ and distant metastasis $(\mathrm{p}=0.008)$ compared to conventional PTC.

Lymph node status and the occurrence of postoperative tumor recurrence or distant metastasis in AC patients were not analyzed together with PTC and DSVPC, as cervical lymph node dissection was performed in only 3 cases and 6 cases were obtained by excisional biopsy. However, 11 (91.7\%) of the $12 \mathrm{AC}$ patients died of disease within 13 months of diagnosis, while tumor-related deaths were not seen for the other two types of thyroid cancers, suggesting that $\mathrm{AC}$ has a remarkably unfavorable prognosis.

\section{DSVPC and AC Are Associated with Significant}

Stromal Caveolin-1 and Caveolin-2 Expression

The immunohistochemical stain results for caveolin-1, caveolin-2 and caveolin-3 in the epithelial and stromal components of PTC, DSVPC and AC are demonstrated in table 3 , figure 1 and figure 2 . The pattern of caveolin expression was membranous and/or cytoplasmic. Caveolin-1 was expressed in the epithelial compart- 

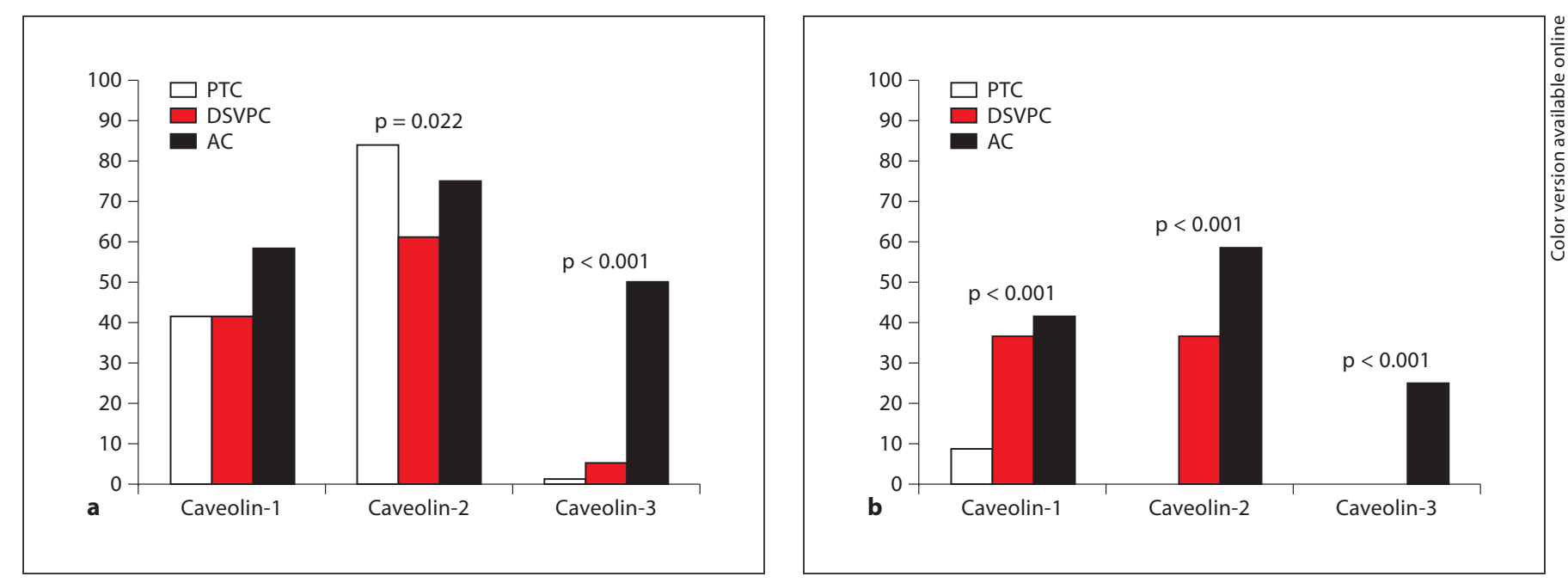

Fig. 2. Bar charts demonstrating the frequency of caveolin-1, caveolin-2 and caveolin-3 expression in the tumor cells (a) and stroma (b) of PTC, DSVPC and AC. The statistically significant p values are shown.

ments of all three types of thyroid cancers with similar frequencies, and although caveolin-2 expression was also seen in all three tumors, epithelial caveolin-2 expression was relatively less frequent in DSVPC and the squamoid cell nests within DSVPC were negative for caveolin-2 expression. A significant increase in stromal caveolin-1 $(\mathrm{p}<0.001)$ and caveolin-2 $(\mathrm{p}<0.001)$ expression was seen in DSVPC and AC compared to PTC.

\section{Caveolin-3 Is Significantly Expressed in the Tumor \\ Cells and Stroma of AC}

Interestingly, epithelial caveolin-3 was seen in $50 \%$ of ACs, while only rare cases of PTC and DSVPC expressed caveolin-3 in the tumor cells ( $\mathrm{p}<0.001)$. In addition, stromal caveolin-3 expression was specifically found only in AC $(\mathrm{p}<0.001)$. As caveolin-3 has been reported to be specifically expressed in myocytes [12,13], we performed additional immunohistochemical stains for SMA for 3 caveolin-3-positive AC, 3 caveolin-3-negative AC and 6 caveolin-3-negative DSVPC in order to search for any differences in the staining patterns between these cases. As expected, positive cytoplasmic staining for SMA was recognized in the caveolin-3-positive stromal cells of AC, while caveolin-3-negative AC were negative for SMA. SMA positivity was found in a few scattered spindle cells in regions of sclerosis in DSVPC, and the staining was patchy and membranous, suggestive of fibroblasts rather than myofibroblasts (fig. 3). The expression of caveolin-1, caveolin-2 and caveolin-3 was not significantly related to the cell type of AC.

Caveolin Expression in Thyroid Cancer
Table 4. Expression of cytokeratin, vimentin and E-cadherin in tumor cells of PTC, DSVPC and AC

\begin{tabular}{|c|c|c|c|c|c|}
\hline & $\begin{array}{l}\text { Total } \\
(\mathrm{n}=123)\end{array}$ & $\begin{array}{l}\text { PTC } \\
(\mathrm{n}=70)\end{array}$ & $\begin{array}{l}\text { DSVPC } \\
(\mathrm{n}=41)\end{array}$ & $\begin{array}{l}\mathrm{AC} \\
(\mathrm{n}=12)\end{array}$ & $\begin{array}{l}\mathrm{p} \\
\text { value }\end{array}$ \\
\hline Cytokeratir & & & & & 0.003 \\
\hline Positive & $120(97.6)$ & $69(98.6)$ & $41(100.0)$ & $10(83.3)$ & \\
\hline Negative & $3(2.4)$ & $1(1.4)$ & & $2(16.7)$ & \\
\hline Vimentin & & & & & $<0.001$ \\
\hline Positive & $24(19.5)$ & $8(11.4)$ & $7(17.1)$ & $9(75.0)$ & \\
\hline Negative & $99(80.5)$ & $62(88.6)$ & 34 (82.9) & $3(25.0)$ & \\
\hline E-cadherin & & & & & $<0.001$ \\
\hline Positive & $114(92.7)$ & $67(95.7)$ & $40(97.6)$ & $6(50.0)$ & \\
\hline Negative & $9(7.3)$ & $3(4.3)$ & $1(2.4)$ & $6(50.0)$ & \\
\hline
\end{tabular}

Figures in parentheses are percentages.

\section{Expression of EMT-Related Proteins in Thyroid \\ Cancer}

The immunohistochemical stain results for cytokeratin, vimentin and E-cadherin in thyroid cancers are summarized in table 4 and figure 4 . Cytokeratin and Ecadherin were more frequently negative in $\mathrm{AC}$ in contrast to PTC and DSVPC ( $p=0.003$ and $p<0.001$, respectively), while vimentin was more frequently expressed in AC in contrast to PTC and DSVPC (both $\mathrm{p}<$ 0.001). Cytokeratin and E-cadherin expression was not seen in the tumor stroma, while the stromal cells ex- 

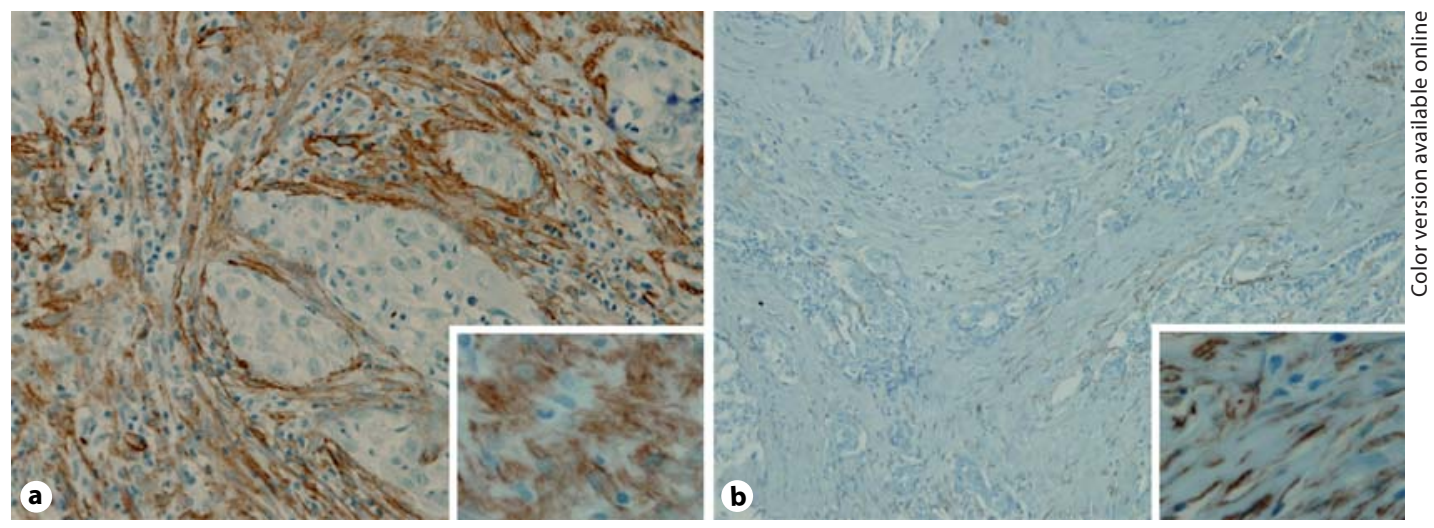

Fig. 3. Expression of SMA in AC and DSVPC. Dense cytoplasmic SMA expression is seen in the tumor stroma (inset) of caveolin-3-positive AC (a), whereas SMA is focally and weakly expressed with a membranous pattern (inset) in the stroma of DSVPC (b).

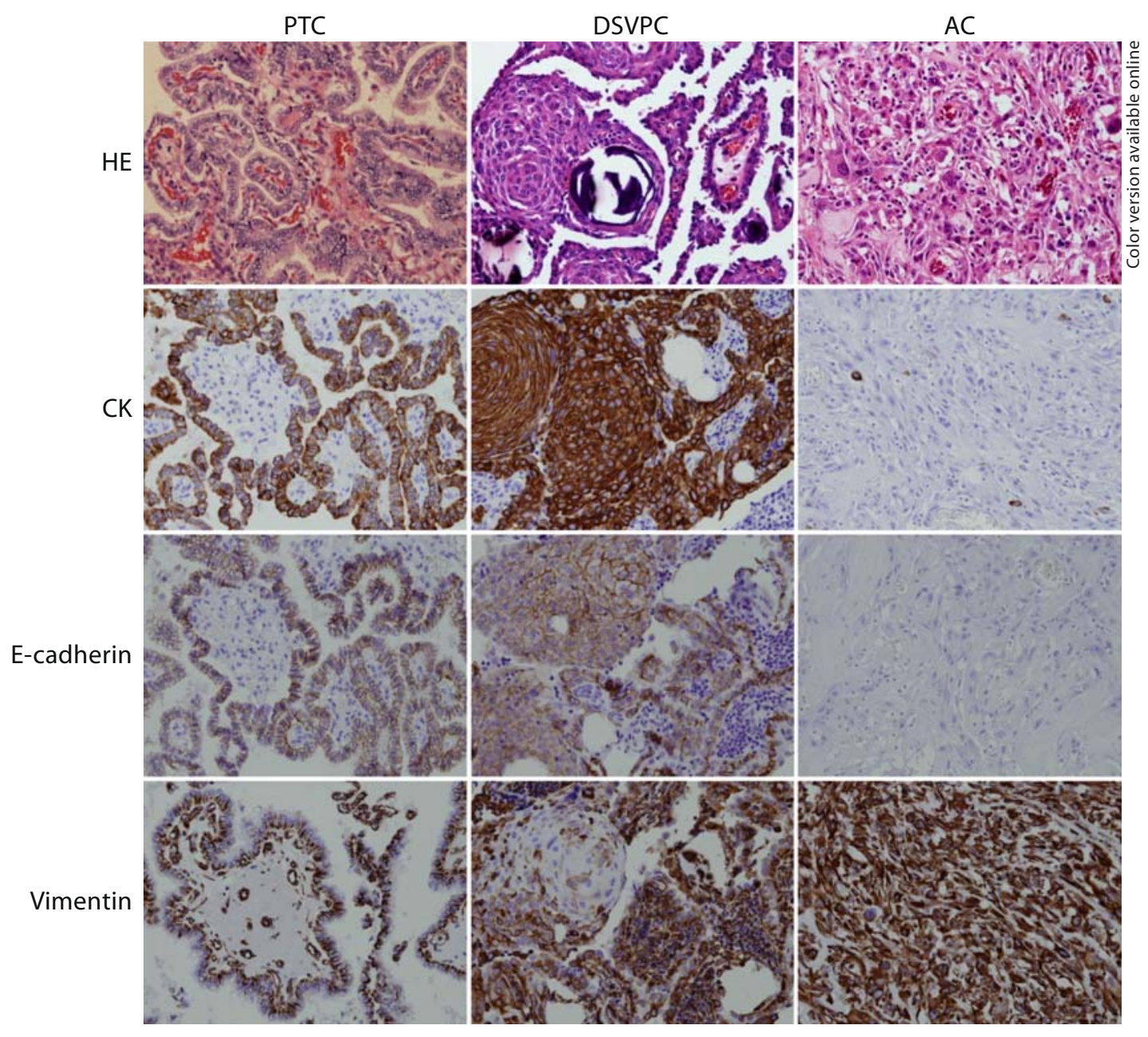

Fig. 4. Expression of cytokeratin (CK), E-cadherin and vimentin in PTC, DSVPC and AC. CK and Ecadherin are negative in the tumor cells of AC, while vimentin is positive. PTC and DSVPC are negative for vimentin and positive for $\mathrm{CK}$ and E-cadherin. 
Table 5. Relationships between caveolin-1, caveolin-2 and caveolin-3 expression and the clinicopathologic parameters of thyroid cancer

\begin{tabular}{|c|c|c|c|c|c|c|c|c|c|c|c|c|c|c|c|c|c|c|}
\hline \multirow[t]{2}{*}{ Parameters } & \multicolumn{2}{|c|}{$\begin{array}{l}\text { Epithelial } \\
\text { caveolin-1 }\end{array}$} & \multirow[t]{2}{*}{$\begin{array}{l}\mathrm{p} \\
\text { value }\end{array}$} & \multicolumn{2}{|c|}{$\begin{array}{l}\text { Stromal } \\
\text { caveolin-1 }\end{array}$} & \multirow[t]{2}{*}{$\begin{array}{l}\mathrm{p} \\
\text { value }\end{array}$} & \multicolumn{2}{|c|}{$\begin{array}{l}\text { Epithelial } \\
\text { caveolin-2 }\end{array}$} & \multirow[t]{2}{*}{$\begin{array}{l}\mathrm{p} \\
\text { value }\end{array}$} & \multicolumn{2}{|c|}{$\begin{array}{l}\text { Stromal } \\
\text { caveolin-2 }\end{array}$} & \multirow[t]{2}{*}{$\begin{array}{l}\mathrm{p} \\
\text { value }\end{array}$} & \multicolumn{2}{|c|}{$\begin{array}{l}\text { Epithelial } \\
\text { caveolin-3 }\end{array}$} & \multirow[t]{2}{*}{$\begin{array}{l}\mathrm{p} \\
\text { value }\end{array}$} & \multicolumn{2}{|c|}{$\begin{array}{l}\text { Stromal } \\
\text { caveolin-3 }\end{array}$} & \multirow[t]{2}{*}{$\begin{array}{l}\mathrm{p} \\
\text { value }\end{array}$} \\
\hline & + & - & & + & - & & + & - & & + & - & & + & - & & + & - & \\
\hline Age & & & 0.718 & & & 0.726 & & & 0.540 & & & 0.954 & & & 0.022 & & & 0.037 \\
\hline$<45$ years & 32 & 40 & & 16 & 56 & & 53 & 19 & & 13 & 59 & & 2 & 70 & & 0 & 72 & \\
\hline$\geq 45$ years & 21 & 30 & & 10 & 41 & & 40 & 11 & & 9 & 42 & & 7 & 44 & & 3 & 48 & \\
\hline Sex & & & 0.032 & & & 0.437 & & & 0.017 & & & 0.513 & & & 0.724 & & & 0.480 \\
\hline Female & 39 & 62 & & 20 & 81 & & 72 & 29 & & 17 & 84 & & 7 & 94 & & 2 & 99 & \\
\hline Male & 14 & 8 & & 6 & 16 & & 21 & 1 & & 5 & 17 & & 2 & 20 & & 1 & 21 & \\
\hline Tumor size & & & 0.632 & & & 0.621 & & & 0.909 & & & $<0.001$ & & & $<0.001$ & & & $<0.001$ \\
\hline$<2 \mathrm{~cm}$ & 16 & 25 & & 10 & 31 & & 31 & 10 & & 7 & 34 & & 0 & 41 & & 0 & 41 & \\
\hline $2-4 \mathrm{~cm}$ & 29 & 38 & & 12 & 55 & & 50 & 17 & & 7 & 60 & & 3 & 64 & & 0 & 67 & \\
\hline$\geq 4 \mathrm{~cm}$ & 8 & 7 & & 4 & 11 & & 12 & 3 & & 8 & 7 & & 6 & 9 & & 3 & 12 & \\
\hline Tumor laterality & & & 0.494 & & & 0.161 & & & 0.886 & & & $<0.001$ & & & 0.186 & & & 0.055 \\
\hline Unilateral & 27 & 40 & & 11 & 56 & & 51 & 16 & & 4 & 63 & & 3 & 64 & & 0 & 67 & \\
\hline Bilateral & 26 & 30 & & 15 & 41 & & 42 & 14 & & 18 & 38 & & 6 & 50 & & 3 & 53 & \\
\hline Metastatic lymph & lodes & & 0.812 & & & 0.242 & & & 0.758 & & & 0.014 & & & 0.245 & & & 0.455 \\
\hline$<8$ & 29 & 45 & & 13 & 61 & & 54 & 20 & & 7 & 67 & & 2 & 72 & & 1 & 73 & \\
\hline$\geq 8$ & 17 & 24 & & 11 & 30 & & 31 & 10 & & 11 & 30 & & 3 & 38 & & 0 & 41 & \\
\hline Tumor extent & & & 0.095 & & & 0.259 & & & 0.339 & & & 0.140 & & & 0.197 & & & 0.468 \\
\hline Intrathyroidal & 11 & 7 & & 2 & 16 & & 12 & 6 & & 1 & 17 & & 0 & 18 & & 0 & 18 & \\
\hline Extrathyroidal & 42 & 63 & & 24 & 81 & & 81 & 24 & & 21 & 84 & & 9 & 96 & & 3 & 102 & \\
\hline
\end{tabular}

pressed vimentin in all cases. When the EMT-related marker expression status was correlated with the cell type of AC, the two cytokeratin-positive cases were both undifferentiated types; however, there were no other significant relationships.

\section{Relationships between Expression of Caveolin-1,}

Caveolin-2 and Caveolin-3 and the Clinicopathologic

\section{Parameters}

The relationships between the caveolin expression status and the clinicopathologic variables are summarized in table 5. Epithelial caveolin-1 and caveolin-2 expression were more common in males compared to females ( $\mathrm{p}=$ 0.032 and $p=0.017$, respectively), and epithelial and stromal caveolin-3 expression was more common in patients aged more than 45 years $(\mathrm{p}=0.022$ and $\mathrm{p}=0.037$, respectively). Stromal caveolin-2 was frequent in tumors with bilateral lobe involvement $(\mathrm{p}<0.001)$ and lymph node metastases in 8 or more lymph nodes $(p=0.014)$. Larger tumors were characterized by more frequent stromal caveolin-2 expression, and epithelial or stromal caveolin-3 expression $(\mathrm{p}<0.001)$.

\section{Discussion}

There is limited data available in the literature on the expression status of caveolin proteins in thyroid cancers, especially in the cancerous stroma, and the existing literature has mostly focused on caveolin-1 and caveolin-2 $[4,5,14]$, while caveolin- 3 expression has not been studied. In this study, we evaluated the expression status of caveolin-1, caveolin-2 and caveolin-3 in PTC, DSVPC and $\mathrm{AC}$, and looked at the cancerous stroma in more detail. Our data shows that caveolin-1 is expressed in the tumor cells with similar frequencies in PTC, DSVPC and AC, which contradicts the results of a previous study that suggested a role for caveolin-1 in early PTC carcinogenesis by demonstrating a reduced expression of caveolin-1 in AC compared to a high expression frequency in papillary microcarcinomas [4]. However, the latter study was performed using an antibody which specifically detects the $\alpha$-isoform of caveolin-1, while we used an antibody that detects both $\alpha$ - and $\beta$-isoforms. Indeed, a high frequency of caveolin-1 expression (78\%) was seen in AC in a different study by Aldred et al. [14] who used the same antibody. 
Caveolin-3, known to be specifically expressed in muscle cells [12, 13] and in rhabdomyosarcomas [15], was interestingly expressed in the tumor cells of a remarkable proportion (50\%) of ACs, which it was only expressed in rare cases of PTC and DSVPC. A plausible explanation for the increased caveolin-3 expression in AC tumor cells may be the association between AC and epithelial-mesenchymal transition (EMT). In general, EMT involves gain in cell motility, expression of mesenchymal cadherins such as $\mathrm{N}$-cadherin and vimentin, and accumulation of $\beta$-catenin, loss of cytokeratin and cell junction proteins such as E-cadherin [16, 17]. AC is characterized by these features of EMT; although AC has various histological forms, the most common histologic pattern is the spindle cell pattern, which is characteristic of cells undergoing EMT [18]. In addition, while AC shows more frequent negativity for cytokeratin and E-cadherin by immunohistochemistry compared to PTC [19], N-cadherin and vimentin are expressed in AC [20], and approximately $65 \%$ of $A C$ harbor $\beta$-catenin mutations, resulting in the accumulation of nuclear $\beta$-catenin $[21,22]$. This study also shows more frequent vimentin expression and less frequent cytokeratin and E-cadherin expression in $\mathrm{AC}$ compared to PTC and DSVPC. However, there were no significant relationships between the EMT-marker expression status and the cell type of AC, suggesting that the EMT phenomenon is not necessarily related to the morphological features of AC. The most notable characteristic of the EMT signature in tumors is the increase in tumor invasiveness due to the gain of cell motility [23, 24]. AC is associated with a widely invasive growth, infiltrating to the soft tissues outside the parenchymal boundaries: extrathyroidal spread was seen in $100 \%$ of $\mathrm{AC}$ in this study. As caveolin-3 is specifically expressed in myocytes, it could be postulated that AC may acquire a myogenic phenotype as part of the EMT process and hence express caveolin-3. DSVPC, on the other hand, has been frequently associated with younger age at diagnosis, extensive lymph node metastasis, frequent local recurrence and distant metastasis compared to conventional PTC, as also shown in this study $[3,25,26]$. However, although DSVPC is associated with features of invasiveness, suggesting that EMT may play a considerable role, the expression of caveolin-3 was rare (4.9\%) in DSVPC in contrast to AC. As the overall prognosis of DSVPC is favorable compared to AC despite these aggressive features, it would be interesting to see in a larger study population whether caveolin-3 expression in DSVPC may identify a subset of these tumors with an aggressive behavior and poor prognosis.
As for the stromal expression of caveolins, significant increases in caveolin-1, caveolin-2 and caveolin-3 expression were seen from PTC, DSVPC to AC $(p<0.001)$. The tumor stroma is composed of cellular components including fibroblasts, myofibroblasts, leukocytes, endothelial cells and bone marrow-derived cells as well as the extracellular matrix $[6,7]$. The expression of caveolin in stromal cells has not been studied in thyroid cancers, while caveolin expression has been recognized in the stroma of breast cancers. The loss of stromal caveolin-1 in breast cancers has been associated with advanced tumor and nodal stages, early tumor recurrence, lymph node metastasis, tamoxifen resistance and poor clinical outcome $[2,27]$, and these stromal cells without caveolin-1 expression have been suggested to have similar characteristics to those of cancer-associated fibroblasts (CAF). CAF are important constituents of the tumor stroma, and are composed of fibroblasts and myofibroblasts. They are involved in neoangiogenesis, tumor cell proliferation, tumor cell invasion and subsequently tumor progression [10, 28-30]. In this study, there was no significant relationship between stromal caveolin-1 expression status and any of the clinicopathologic factors, and therefore it could be suggested that the role of CAF is not substantial in thyroid cancers.

While caveolin- 1 and caveolin-2 were expressed in the stroma of PTC and/or DSVPC, caveolin-3 expression was specifically expressed in the stroma of $\mathrm{AC}$, which is interesting as caveolin-1 and caveolin-2 is expressed in a variety of stromal cells including fibroblasts, whereas caveolin-3 is only expressed in muscle cells. The caveolin-3positive stroma of AC may consist of myofibroblasts, and in order to look further into this possibility, we performed additional immunohistochemical stains for SMA in selected cases of AC and DSVPC. As expected, cytoplasmic SMA positivity was noticed in the caveolin-3-positive stromal cells, suggestive of a myogenic phenotype. Large numbers of myofibroblasts, which express SMA and caveolin-3, have been identified in the stroma of human breast cancers [28, 31]: the myofibroblast is a dominant component of the CAF, and is known to participate in the wound healing process [32] and stromal response to tumors $[7,33]$. In addition, cancers with greater myofibroblast stromal reactions have been associated with poor prognoses [34-36]. The myofibroblasts in the stroma of AC may originate from various cells, including pre-existing fibroblasts, preadipocytes, smooth muscle cells, endothelial cells, epithelial cells, bone marrow-derived progenitors [37-41] or also from the tumor cells themselves as part of the EMT process. The stromal cells of DSVPC 
were negative for caveolin-3 and staining for SMA was patchy and membranous as seen in fibroblasts. This is not surprising, as the fibrosis in DSVPC is typically of the sclerosing type suggestive of a late stage in the fibrosing process, rather than an active fibrosis where myofibroblasts would be present.

When the expression statuses of the caveolins were correlated with the clinicopathologic parameters, epithelial caveolin-1 or caveolin-2 expression was not significantly correlated with patient age or any features related to the aggressiveness of the tumors. On the contrary, stromal caveolin-2 expression was associated with increased tumor size, bilaterality of tumors and higher numbers of metastatic lymph nodes, and thyroid cancers with epithelial and/or stromal caveolin-3 were characterized by older age at presentation and larger tumors. The latter fea- tures probably reflect the characteristics of AC, as caveolin-3 was specifically expressed in the stroma of AC and epithelial caveolin-3 expression was only rarely seen in PTC and DSVPC. In addition, thyroid cancers with stromal caveolin-2 expression were composed of the DSVPC and $\mathrm{AC}$ groups, and therefore the aggressive clinicopathologic features of the stromal caveolin-2-positive cases may also reflect the characteristics of DSVPC and AC.

In conclusion, epithelial caveolin-3 expression was more frequent in AC compared to PTC and DSVPC, and this could be related to the EMT phenomenon. In addition, stromal caveolin-1, caveolin-2 and caveolin-3 expression were more frequent in AC and DSVPC compared to conventional PTC, and from the specific stromal caveolin-3 expression in AC in this study it could be suggested that myofibroblasts are present in the tumor stroma of AC.

\section{References}

-1 Cohen AW, Hnasko R, Schubert W, Lisanti MP: Role of caveolae and caveolins in health and disease. Physiol Rev 2004;84:1341-1379.

$\checkmark 2$ Sloan EK, Ciocca DR, Pouliot N, Natoli A, Restall C, Henderson MA, Fanelli MA, Cuello-Carrion FD, Gago FE, Anderson RL: Stromal cell expression of caveolin-1 predicts outcome in breast cancer. Am J Pathol 2009; 174:2035-2043.

3 Carcangiu ML, Bianchi S: Diffuse sclerosing variant of papillary thyroid carcinoma. Clinicopathologic study of 15 cases. Am J Surg Pathol 1989;13:1041-1049.

4 Ito Y, Yoshida H, Nakano K, Kobayashi K, Yokozawa T, Hirai K, Matsuzuka F, Matsuura N, Kakudo K, Kuma K, Miyauchi A: Caveolin-1 overexpression is an early event in the progression of papillary carcinoma of the thyroid. Br J Cancer 2002;86:912-916.

$\checkmark 5$ Ito Y, Yoshida H, Tomoda C, Uruno T, Takamura Y, Miya A, Kobayashi K, Matsuzuka F, Nakamura Y, Kakudo K, Kuma K, Miyauchi A: Caveolin-1 and 14-3-3 $\sigma$ expression in follicular variant of thyroid papillary carcinoma. Pathol Res Pract 2005;201:545-549.

6 Bissell MJ, Radisky D: Putting tumours in context. Nat Rev Cancer 2001;1:46-54.

-7 Kalluri R, Zeisberg M: Fibroblasts in cancer. Nat Rev Cancer 2006;6:392-401.

8 Bhowmick NA, Neilson EG, Moses HL: Stromal fibroblasts in cancer initiation and progression. Nature 2004;432:332-337.

$\checkmark 9$ Mueller MM, Fusenig NE: Friends or foes bipolar effects of the tumour stroma in cancer. Nat Rev Cancer 2004;4:839-849.

-10 Orimo A, Weinberg RA: Stromal fibroblasts in cancer: a novel tumor-promoting cell type. Cell Cycle 2006;5:1597-1601
11 Polyak K, Haviv I, Campbell IG: Co-evolution of tumor cells and their microenvironment. Trends Genet 2009;25:30-38.

12 Lisanti MP, Scherer PE, Tang Z, Sargiacomo M: Caveolae, caveolin and caveolin-rich membrane domains: a signalling hypothesis. Trends Cell Biol 1994;4:231-235.

13 Lisanti MP, Tang Z, Scherer PE, Kubler E, Koleske AJ, Sargiacomo M: Caveolae, transmembrane signalling and cellular transformation. Mol Membr Biol 1995;12:121-124.

14 Aldred MA, Ginn-Pease ME, Morrison CD, Popkie AP, Gimm O, Hoang-Vu C, Krause U, Dralle H, Jhiang SM, Plass C, Eng C: Caveolin-1 and caveolin-2, together with three bone morphogenetic protein-related genes, may encode novel tumor suppressors downregulated in sporadic follicular thyroid carcinogenesis. Cancer Res 2003;63:2864-2871.

15 Fine SW, Lisanti MP, Argani P, Li M: Caveolin-3 is a sensitive and specific marker for rhabdomyosarcoma. Appl Immunohistochem Mol Morphol 2005;13:231-236.

16 Lee J, Dedhar S, Kalluri R, Thompson E: The epithelial-mesenchymal transition: new insights in signaling, development, and disease. J Cell Biol 2006;172:973-981.

-17 Blick T, Widodo E, Hugo H, M. W, Lenburg M, Neve R, Thompson E: Epithelial mesenchymal transition traits in human breast cancer cell lines. Clin Exp Metastasis 2008 25:629-642.

18 Carcangiu M, Steeper T, Zampi G, Rosai J: Anaplastic thyroid carcinoma. A study of 70 cases. Am J Clin Pathol 1985;83:135-158.
19 Choi YL, Kim MK, Suh JW, Han J, Kim JH, Yang JH, Nam SJ: Immunoexpression of hbme-1, high molecular weight cytokeratin, cytokeratin 19, thyroid transcription factor-1, and E-cadherin in thyroid carcinomas. J Korean Med Sci 2005;20:853-859.

20 Husmark J, Heldin NE, Nilsson M: N-cadherin-mediated adhesion and aberrant catenin expression in anaplastic thyroid-carcinoma cell lines. Int J Cancer 1999;83:692699.

21 Garcia-Rostan G, Camp R, Herrero A, Carcangiu M, Rimm D, Tallini G: Beta-catenin dysregulation in thyroid neoplasms: downregulation, aberrant nuclear expression, and CTNNB1 exon 3 mutations are markers for aggressive tumor phenotypes and poor prognosis. Am J Pathol 2001;158:987-996.

$\checkmark 22$ Garcia-Rostan G, Tallini G, Herrero A, D’Aquila T, Carcangiu M, Rimm D: Frequent mutation and nuclear localization of $\beta$ catenin in anaplastic thyroid carcinoma. Cancer Res 1999;59:1811-1815.

23 Thiery J: Epithelial-mesenchymal transitions in tumour progression. Nat Rev Cancer 2002;2:442-454

-24 Thompson E, Newgreen D, Tarin D: Carcinoma invasion and metastasis: a role for epithelial-mesenchymal transition? Cancer Res 2005;65:5991-5995.

$>25$ Koo JS, Hong S, Park CS: Diffuse sclerosing variant is a major subtype of papillary thyroid carcinoma in the young. Thyroid 2009; 19:1225-1231.

26 Koo JS, Shin E, Hong SW: Immunohistochemical characteristics of diffuse sclerosing variant of papillary carcinoma: comparison with conventional papillary carcinoma. APMIS 2010;118:744-752. 
-27 Witkiewicz AK, Dasgupta A, Nguyen KH, Liu C, Kovatich AJ, Schwartz GF, Pestell RG, Sotgia F, Rui H, Lisanti MP: Stromal caveolin-1 levels predict early DCIS progression to invasive breast cancer. Cancer Biol Ther 2009;8:1071-1079.

-28 Orimo A, Gupta PB, Sgroi DC, ArenzanaSeisdedos F, Delaunay T, Naeem R, Carey VJ, Richardson AL, Weinberg RA: Stromal fibroblasts present in invasive human breast carcinomas promote tumor growth and angiogenesis through elevated sdf-1/cxcl12 secretion. Cell 2005;121:335-348.

-29 Sotgia F, Del Galdo F, Casimiro MC, Bonuccelli G, Mercier I, Whitaker-Menezes D, Daumer KM, Zhou J, Wang C, Katiyar S, Xu $\mathrm{H}$, Bosco E, Quong AA, Aronow B, Witkiewicz AK, Minetti C, Frank PG, Jimenez SA, Knudsen ES, Pestell RG, Lisanti MP: Caveolin-1 $1^{-/}$null mammary stromal fibroblasts share characteristics with human breast cancer-associated fibroblasts. Am J Pathol 2009; 174:746-761.

- 30 Mercier I, Casimiro MC, Wang C, Rosenberg AL, Quong J, Minkeu A, Allen KG, Danilo C, Sotgia F, Bonuccelli G, Jasmin JF, Xu H, Bosco E, Aronow B, Witkiewicz A, Pestell RG, Knudsen ES, Lisanti MP: Human breast cancer-associated fibroblasts (CAFs) show caveolin-1 downregulation and $\mathrm{RB}$ tumor suppressor functional inactivation: implications for the response to hormonal therapy. Cancer Biol Ther 2008;7:1212-1225.
31 Barth K, Reh J, Sturrock A, Kasper M: Epithelial vs myofibroblast differentiation in immortal rat lung cell lines - modulating effects of bleomycin. Histochem Cell Biol 2005;124:453-464.

32 Gabbiani G, Ryan G, Majne G: Presence of modified fibroblasts in granulation tissue and their possible role in wound contraction. Experientia 1971;27:549-550.

33 Sappino AP, Skalli O, Jackson B, Schurch W, Gabbiani G: Smooth-muscle differentiation in stromal cells of malignant and non-malignant breast tissues. Int J Cancer 1988;41:707712 .

34 Cardone A, Tolino A, Zarcone R, Borruto Caracciolo G, Tartaglia E: Prognostic value of desmoplastic reaction and lymphocytic infiltration in the management of breast cancer. Panminerva Med 1997;39:174-177.

35 Kellermann MG, Sobral LM, da Silva SD, Zecchin KG, Graner E, Lopes MA, Kowalski LP, Coletta RD: Mutual paracrine effects of oral squamous cell carcinoma cells and normal oral fibroblasts: induction of fibroblast to myofibroblast transdifferentiation and modulation of tumor cell proliferation. Oral Oncol 2008;44:509-517.
36 Maeshima AM, Niki T, Maeshima A, Yamada T, Kondo H, Matsuno Y: Modified scar grade: a prognostic indicator in small peripheral lung adenocarcinoma. Cancer 2002; 95:2546-2554.

>37 Direkze NC, Hodivala-Dilke K, Jeffery R, Hunt T, Poulsom R, Oukrif D, Alison MR, Wright NA: Bone marrow contribution to tumor-associated myofibroblasts and fibroblasts. Cancer Res 2004;64:8492-8495.

38 Mishra PJ, Humeniuk R, Medina DJ, Alexe G, Mesirov JP, Ganesan S, Glod JW, Banerjee D: Carcinoma-associated fibroblast-like differentiation of human mesenchymal stem cells. Cancer Res 2008;68:4331-4339.

-39 Radisky DC, Kenny PA, Bissell MJ: Fibrosis and cancer: do myofibroblasts come also from epithelial cells via emt? J Cell Biochem 2007;101:830-839.

40 Ronnov-Jessen L, Petersen OW, Koteliansky VE, Bissell MJ: The origin of the myofibroblasts in breast cancer. Recapitulation of tumor environment in culture unravels diversity and implicates converted fibroblasts and recruited smooth muscle cells. J Clin Invest 1995;95:859-873.

41 Zeisberg EM, Potenta S, Xie L, Zeisberg M, Kalluri R: Discovery of endothelial to mesenchymal transition as a source for carcinoma-associated fibroblasts. Cancer Res 2007; 67:10123-10128. 